\title{
ANALISIS PERSEPSI ANAK TERHADAP GAYA PENGASUHAN ORANGTUA, KECERDASAN EMOSIONAL, AKTIVITAS DAN PRESTASI BELAJAR SISWA KELAS XI DI SMA NEGERI 3 SUKABUMI
}

(Analysis of Children Perspective Parenting Form, Emotional Intelligence, Activities, and Learning Achievement of Students of Eleventh Class Student in SMA Negeri 3 Sukabumi)

$$
\text { Riza Arisandi }{ }^{1} \text { dan Melly Latifah }{ }^{2}
$$

\begin{abstract}
The study aimed to analyze child's perception on parenting style, level of emotional intelligence and academic achievement of high school students at SMA 3 Sukabumi. Results showed that more than 60 percent student perceived that parenting style is classified as emotional coach. In general level of EQ of the students classified as moderate (62.8\%) while the rest classified as high. There was significant difference in term of duration of student activities based on classes (IPA or IPS) while by gender there was not significance. Academic achievement of girls was significantly higher than boys, also their motor achievement. Parenting style of the parent was significantly correlated with EQ of student, particularly in term of emotional awareness, self motivation, social relationship, and total EQ. In line with this total EQ and social relationship have positive and significant correlation with cognitive achievement, while empathy, social relationship and total EQ also have significant associations with motor achievement. Only self motivation was significantly related to attitude of students.
\end{abstract}

Keywords: parenting, emotional intelligence, academic achievement, senior high school students

\section{PENDAHULUAN}

Kecerdasan emosional pada masa remaja diperlukan sebagai bekal keterampilan emosi dan sosial untuk mengenali, mengolah, dan mengontrol emosi dalam mengatasi berbagai rintangan hidup. Kecerdasan emosional yang dimiliki didapatkan melalui peran pengasuhan orangtua. Menurut Goleman (1997) orangtua yang terampil secara emosional memiliki anak-anak yang pergaulannya lebih baik, memperlihatkan lebih banyak kasih saying, lebih pintar menangani emosi dan lebih efektif menenangkan diri saat marah. Remaja dengan kecerdasaan emosional tinggi cenderung aktif di berbagai aktivitas dan memiliki prestasi belajar yang baik.

Penelitian ini bertujuan untuk menganalisis persepsi remaja terhadap gaya pengasuhan orangtua, kecerdasan emosional, aktivitas, dan prestasi belajar siswa kelas XI di Sekolah Menengah Atas Negeri 3
Sukabumi. Secara khusus penelitian ini bertujuan untuk ;1) menganalisis keragaan gaya pengasuhan orangtua; 2) menganalisis keragaan kecerdasan emosional, aktivitas, dan prestasi belajar siswa berdasarkan jenis kelamin dan kelas (IPA atau IPS); 3) menganalisis hubungan gaya pengasuhan orangtua dengan kecerdasan emosional; 4) menganalisis hubungan kecerdasan emosional dengan aktivitas dan prestasi belajar siswa ; 5) menganalisis hubungan aktivitas dengan prestasi belajar siswa.

\section{METODE}

Tempat dan Waktu Penelitian

Penelitian dilakukan di Sekolah Menengah Atas Negeri 3 (SMAN 3) Sukabumi yang terletak di jalan Ciaul Pasir No. 21 Kota Sukabumi, Propinsi Jawa Barat. Pengumpulan data dilakukan pada bulan April sampai Mei 2007. 
Cara Pemilihan Contoh

Contoh penelitian ini adalah siswa kelas 11 SMAN 3 Sukabumi, dengan pertimbangan siswa kelas 11 telah memiliki pengalaman belajar di SMA relatif cukup lama dibandingkan kelas 10, tetapi tidak disibukkan dengan persiapan Ujian Akhir Nasional seperti kelas 12. Populasi penelitian sejumlah 364 siswa yang terdiri dari kelas 11 IPA (202 siswa) dan kelas 11 IPS (162 siswa). Jumlah populasi target yaitu sejumlah 100 siswa, kemudian dipilih sejumlah 78 siswa agar dapat memenuhi jumlah contoh minimal yang diperlukan. Sampel penelitian dihitung menggunakan formula Slovin (1960) diacu dalam Umar, H (2003) sebagai berikut :

$$
n=\frac{N}{1+N e^{2}}
$$

Jenis dan Cara Pengumpulan Data

Jenis data yang dikumpulkan
meliputi data primer dan data sekunder. Data primer dikumpulkan dengan alat bantu kuisioner yang diisi oleh contoh setelah mendapat penjelasan dari peneliti. Data sekunder meliputi prestasi belajar dan keadaan umum sekolah yang diperoleh dari pihak sekolah.

\section{Pengolahan dan Analisis Data}

Data yang diperoleh diolah dan dianalisis secara deskriptif dan inferensial dengan menggunakan program komputer Statistical Package for Sosial Science (SPSS) versi 13.0 for Windows. Proses pengolahan meliputi editing, coding, entry, scoring, dan cleaning data. Data deskriptif yang sudah diolah disajikan dalam bentuk tabel frekuensi. Uji beda yang digunakan adalah uji beda MannWhitney (data berskala nominal) dan uji beda $T$-test (data berskala rasio).

\section{HASIL DAN PEMBAHASAN}

Karakteristik Keluarga

Apabila dilihat dari besar keluarga, contoh menyebar pada keluarga kecil dan sedang dengan proporsi yang hampir sama. Menurut Pulung (1993) diacu dalam Soetjiningsih (1995), besar keluarga akan mempengaruhi tingkah laku anak. Semakin besar keluarga, maka semakin sedikit perhatian yang diperoleh anak dari orangtua.

Berdasarkan
orangtua, jumlah ayah yadikan berpendidikan Perguruan Tinggi lebih besar dari ibu, sedangkan jumlah ayah yang berpendidikan SMA sama dengan ibu. Dapat disimpulkan bahwa kelompok pendidikan ayah dan ibu contoh termasuk kategori baik dan pendidikan ayah cenderung lebih tinggi dari ibu.

Rata-rata pendapatan per kapita per bulan sebesar Rp 706 350.42. Bila dilihat berdasarkan Produk Domestik Regional Bruto (PDRB) (BPS 2002), pendapatan per kapita per bulan masyarakat Sukabumi, sebesar Rp 462 052. Dengan demikian, keluarga contoh memiliki pendapatan rata-rata di atas rata-rata PDRB Sukabumi. Menurut Gunarsa dan Gunarsa (2004), keadaan ekonomi keluarga yang cukup menyebabkan orangtua lebih mempunyai waktu untuk membimbing anak karena orangtua tidak lagi memikirkan tentang keadaan ekonomi yang kurang.

\section{Gaya Pengasuhan Orangtua}

Seperti disajikan pada gambar 1 hampir seluruh orangtua contoh (93.6\%) memiliki gaya pengasuhan laissez faire dalam kategori sedang, dan lebih dari setengah orangtua contoh (60.3\%) memiliki gaya pelatih emosi dalam kategori tinggi. Menurut Gottman dan Claire (1998), seorang anak yang memiliki orangtua pelatih emosi akan memiliki kecerdasan emosional yang baik, kesehatan fisik 
yang baik, dan memiliki hubungan dengan teman yang baik.

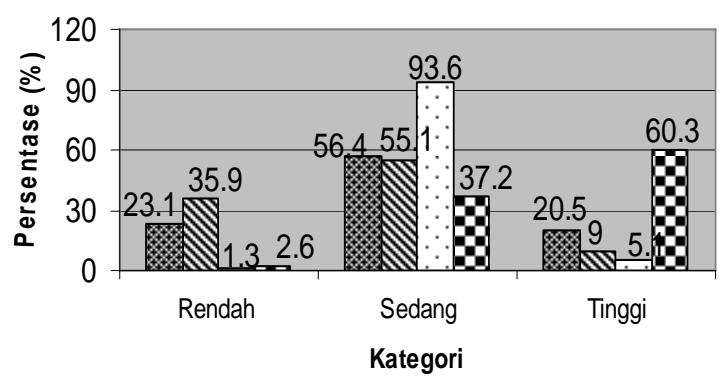

Orangtua Mengabaikan

₫ Orangtua Tidak Menyetujui

$\checkmark$ Orangtua Laissez Faire

口 Orangtua Pelatih Emosi

Gambar 1. Sebaran contoh berdasarkan kecenderungan gaya pengasuhan orangtua

Pada tabel 1 tampak bahwa kecerdasan emosional contoh pada skala kesadaran emosi diri, pengelolaan emosi diri, motivasi diri dan seni membina hubungan sebagian besar berada pada kategori cukup (60.3\%, 59.0, 70.5\% dan 56.4\%) dan kurang dari 40 persen termasuk kategori baik $(38.5 \%, 33.3 \%, 24.4 \%$ dan $35.9 \%$ ) pada keempat skala kecerdasan emosional tersebut. Sebaliknya untuk empati, lebih dari separuh contoh berada pada kategori baik (52.6\%). Secara umum menunjukkan bahwa lebih dari separuh contoh berada pada kategori cukup $(62.8 \%)$ dan sisanya kategori baik.

Jika dilihat kecerdasan emosional pada laki-laki dan perempuan, maka hasil uji beda MannWhitney menunjukkan bahwa tidak terdapat perbedaan nyata dalam kecerdasan emosional antar jenis kelamin. Begitu pula kecerdasan emosional contoh dari kelas IPA dan IPS, menunjukkan bahwa tidak terdapat perbedaan nyata dalam kecerdasan emosional antara kedua kelompok.

Tabel 1. Sebaran contoh berdasarkan kecerdasan emosional

\begin{tabular}{|c|c|c|r|r|r|r|r|r|}
\hline \multirow{2}{*}{ No } & \multicolumn{2}{|c|}{$\begin{array}{c}\text { Kecerdasan } \\
\text { Emosional }\end{array}$} & \multicolumn{2}{|c|}{$\begin{array}{c}\text { Kangat } \\
\text { kurang }\end{array}$} & Kurang & Cukup & Baik & $\begin{array}{c}\text { Sangat } \\
\text { Baik }\end{array}$ \\
\hline 1 & $\begin{array}{c}\text { Kesadaran Emosi } \\
\text { Diri }\end{array}$ & $\%$ & 0 & 1.3 & 60.3 & 38.5 & 0 & 100 \\
\hline 2 & $\begin{array}{c}\text { Pengelolaan Emosi } \\
\text { Diri }\end{array}$ & $\%$ & 0 & 6.4 & 59.0 & 33.3 & 1.3 & 100 \\
\hline 3 & Motivasi Diri & $\%$ & 0 & 5.1 & 70.5 & 24.4 & 0 & 100 \\
\hline 4 & Empati & $\%$ & 0 & 0 & 44.9 & 52.6 & 2.6 & 100 \\
\hline 5 & $\begin{array}{c}\text { Membina } \\
\text { Hubungan }\end{array}$ & $\%$ & 1.3 & 3.8 & 56.4 & 35.9 & 2.6 & 100 \\
\hline 6 & $\begin{array}{c}\text { Kecerdasan } \\
\text { Emosional }\end{array}$ & $\%$ & 0 & 0 & 62.8 & 37.2 & & 100 \\
\hline
\end{tabular}

\section{Aktivitas}

Jenis dan rata-rata alokasi waktu. Tabel 2 menunjukkan bahwa rata-rata lama aktivitas waktu luang contoh (4.3 jam/hari/orang) lebih lama daripada waktu yang digunakan untuk aktivits belajar di rumah(1.6 jam/hari/orang). Rata-rata lama akativitas rumah tangga contoh yaitu, selama 0.4 jam per hari. Jenis aktivitas rumah tangga yang dilakukan contoh, yaitu, mencuci piring, membereskan 
rumah, menyapu, dan mengerjakan kebutuhan sekolah seperti mencuci sepatu dan menggosok baju. Lama aktivitas bersosialisasi yang dilakukan contoh \pm 1.4 jam/hari/orang, yaitu bermain, pertemuan keluarga atau seminar dan mengobrol.

Jenis aktivitas dan rata-rata alokasi waktu contoh dari kelas IPA dan IPS, yaitu contoh dari kelas IPA belajar di rumah (+ 2 jam perhari) lebih lama dibandingkan dengan contoh dari kelas IPS (+1.3 jam per hari). Sementara itu, aktivitas menonton televisi, mendengarkan musik dan main game anak dari kelas IPS lebih lama dari anak IPA. Begitu pula ratarata lama aktivitas bersosialisasi anak dari kelas IPS lebih lama daripada anak kelas IPA. Hasil uji beda T-test menunjukkan bahwa memiliki perbedaan dalam aktivitas antar kelas (IPA / IPS).

Tabel 2. Sebaran jenis aktivitas dan rata-rata alokasi waktu berdasarkan jenis kelas

\begin{tabular}{|c|c|c|c|c|}
\hline No & Aktivitas & $\begin{array}{c}\text { Rata-rata Lama } \\
\text { Beraktivitas Anak } \\
\text { IPA } \\
\text { (Jam/hari/orang) }\end{array}$ & $\begin{array}{c}\text { Rata-rata Lama } \\
\text { Beraktivitas Anak } \\
\text { IPS } \\
\text { (Jam/hari/orang) }\end{array}$ & $\begin{array}{c}\text { Rata-rata Lama } \\
\text { Beraktivitas } \\
\text { (Jam/hari/orang) }\end{array}$ \\
\hline 1. & $\begin{array}{l}\text { Aktivitas belajar } \\
\text { di sekolah }\end{array}$ & 5 & 5 & 5 \\
\hline 2 & $\begin{array}{l}\text { Aktivitas belajar } \\
\text { di rumah }\end{array}$ & 2 & 1.3 & 1.6 \\
\hline 3. & $\begin{array}{l}\text { Aktivitas } \\
\text { ekstrakurikuler }\end{array}$ & 0.8 & 0.7 & 0.7 \\
\hline 4. & $\begin{array}{l}\text { Aktivitas rumah } \\
\text { tangga }\end{array}$ & 0.4 & 0.3 & 0.4 \\
\hline 5. & $\begin{array}{l}\text { Aktivitas waktu } \\
\text { luang }\end{array}$ & & & \\
\hline & $\begin{array}{l}\text {-Menonton } \\
\text { Televisi }\end{array}$ & 2.7 & 3.2 & 2.9 \\
\hline & $\begin{array}{l}\text {-Mendengr } \\
\text { kan Musik }\end{array}$ & 0.5 & 0.7 & 0.6 \\
\hline & - Main Game & 0.3 & 0.5 & 0.4 \\
\hline & $\begin{array}{l}\text { - Baca } \\
\text { Majalah/Buku } \\
\text { Cerita }\end{array}$ & 0.5 & 0.3 & \\
\hline 6. & $\begin{array}{l}\text { Aktivitas } \\
\text { bersosialisasi }\end{array}$ & 1.3 & 1.5 & 1.4 \\
\hline \multirow{5}{*}{7.} & Aktivitas pribadi & & & \\
\hline & - Tidur & 8 & 8 & 8 \\
\hline & - Mandi & 0.5 & 0.6 & 0.5 \\
\hline & - Makan & 0.5 & 0.5 & 0.5 \\
\hline & - Ibadah & 0.7 & 0.7 & 0.7 \\
\hline 8. & Aktivitas antara & 0.8 & 0.7 & 0.9 \\
\hline
\end{tabular}

Tabel 3 menunjukkan bahwa rata-rata lama waktu beraktivitas belajar di rumah pada contoh perempuan hampir sama dengan contoh laki-laki $( \pm 1.6$ dan \pm 1.5 jam/hari/orang), sedangkan rata-rata lama aktivitas menonton televisi contoh perempuan maupun laki-laki lebih lama dari belajar $\left(\begin{array}{l} \pm \\ 2.9\end{array}\right.$ jam/hari/orang). Untuk lama aktivitas kurikuler contoh laki-laki, yaitu selama $0.9 \mathrm{jam} / \mathrm{hari}$ lebih lama daripada anak 
perempuan. Selain itu, aktivitas main game pada contoh perempuan lebih lama, yaitu selama 0.5 jam/hari/orang, hasil uji beda T-test menunjukkan bahwa tidak terdapat perbedaan nyata dalam aktivitas antar jenis kelamin.

Tabel 3. Sebaran jenis aktivitas dan rata-rata alokasi waktu berdasarkan jenis kelamin

\begin{tabular}{|c|c|c|c|}
\hline No & Aktivitas & $\begin{array}{c}\text { Rata-rata Lama } \\
\text { Beraktivitas Anak Laki-laki } \\
\text { (Jam/hari/orang) }\end{array}$ & $\begin{array}{c}\text { Rata-rata Lama Beraktivitas } \\
\text { Anak Perempuan } \\
\text { (Jam/hari/orang) }\end{array}$ \\
\hline 1 & $\begin{array}{l}\text { Aktivitas belajar di } \\
\text { sekolah }\end{array}$ & 5 & 5 \\
\hline 2 & $\begin{array}{l}\text { Aktivitas belajar di } \\
\text { rumah }\end{array}$ & 1.5 & 1.6 \\
\hline 3 & Aktivitas ekstrakurikuler & 0.9 & 0.5 \\
\hline 4 & Aktivitas rumah tangga & 0.3 & 0.4 \\
\hline 5 & $\begin{array}{l}\text { Aktivitas waktu luang } \\
\text { - Menonton Televisi } \\
\text { - Mendengarkan } \\
\text { Musik } \\
\text { - Main Game } \\
\text { - Baca Majalah/Buku } \\
\text { Cerita }\end{array}$ & $\begin{array}{l}2.9 \\
0.3 \\
0.3 \\
0.5\end{array}$ & $\begin{array}{l}2.9 \\
0.9 \\
0.5 \\
0.2\end{array}$ \\
\hline 6 & Aktivitas bersosialisasi & 1.3 & 1.4 \\
\hline 7 & $\begin{array}{l}\text { Aktivitas pribadi } \\
\text { - } \quad \text { Tidur } \\
\text { - Mandi } \\
\text { - Makan } \\
\text { - Ibadah }\end{array}$ & $\begin{array}{l}8 \\
0.5 \\
0.5 \\
0.9\end{array}$ & $\begin{array}{l}8 \\
0.5 \\
0.5 \\
0.7\end{array}$ \\
\hline 8 & Aktivitas antara & 0.9 & 0.9 \\
\hline & Total & 24 & 24 \\
\hline
\end{tabular}

Aktivitas ekstrakurikuler. Ektrakurikuler merupakan aktivitas di luar jam belajar di sekolah yang dilakukan contoh di sekolah maupun di luar sekolah. Gambar 2 menunjukkan bahwa contoh dari kelas IPA dan IPS yang mengikuti satu jenis aktivitas ekstrakurikuler memiliki persentase yang hampir sama, yaitu sebesar 32.6 persen dan 34.3 persen. Jumlah aktivitas ekstrakurikuler yang diikuti contoh dari kelas IPA paling banyak empat jenis aktivitas ekatrakurikuler dan hanya dua jenis aktivitas ekstrakurikuler pada contoh kelas IPS. Selain itu, lebih dari separuh contoh dari kelas IPS tidak mengikuti aktivitas ekstrakurikuler.

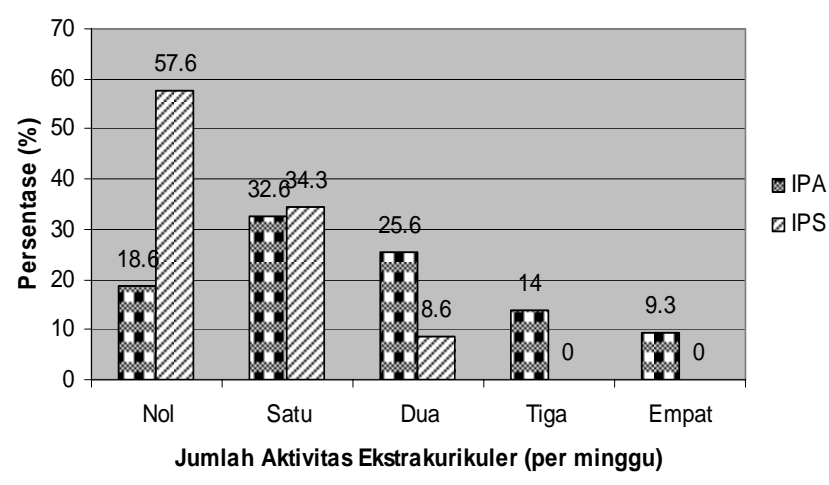

Gambar 2. Sebaran jumlah aktivitas kstrakurikuler contoh berdasarkan jenis kelas 
Gambar 3 menunjukkan bahwa sebesar 41.7 persen pada contoh lakilaki mengikuti satu jenis aktivitas ekstrakurikuler lebih banyak daripada contoh perempuan. Contoh yang mengikuti empat jenis aktivitas ekstrakurikuler per minggu, yaitu sebesar 8.3 persen adalah contoh lakilaki dan kurang dari empat persen adalah perempuan. Persentase terbesar contoh yang tidak mengikuti aktivitas ekstrakurikuler, yaitu pada contoh perempuan (40.7\%).

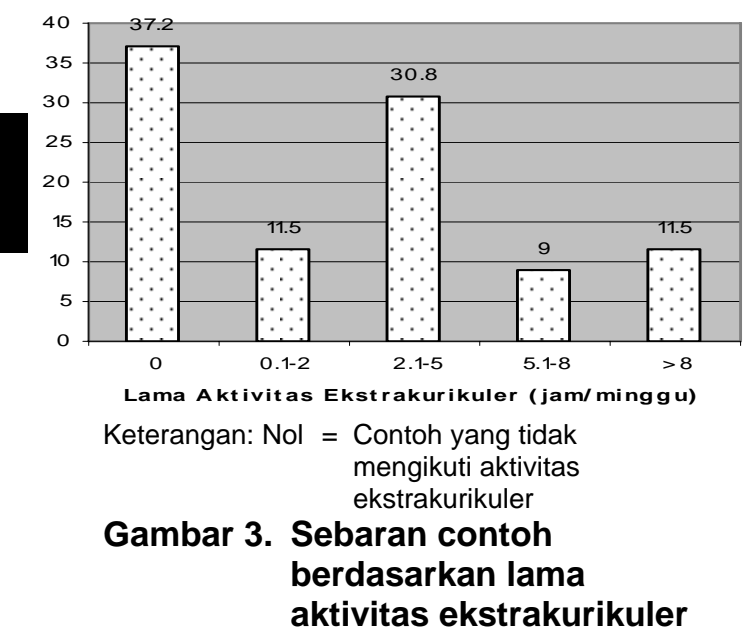

Sebesar 32.6 persen contoh dari kelas IPA mengikuti aktivitas ekstrakurikuler antara 0.1 sampai 3.5 jam per minggunya, dan sebesar 20.9 persen contoh mengikuti aktivitas ekstrakurikuler selama lebih dari 8 jam per minggunya. Sebesar 22.9 persen contoh dari kelas IPS mengikuti ekstrakurikuler antara 0.1 jam sampai 3.5 jam per minggunya, dan sebesar 17.1 persen contoh yang mengikuti ekstrakurikuler selama lebih dari 3.51 jam per minggunya disajikan pada Gambar 4.

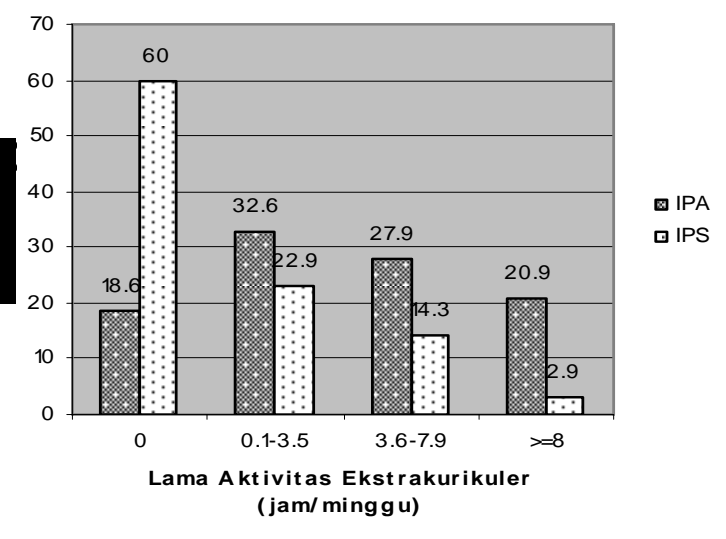

$$
\begin{array}{cl}
\text { Keterangan: } \mathrm{Nol}= & \begin{array}{l}
\text { Contoh yang tidak } \\
\text { mengikuti aktivitas } \\
\text { ekstrakurikuler }
\end{array} \\
\text { Gambar 4. } & \begin{array}{l}
\text { Sebaran lama aktivitas } \\
\text { ekstrakurikuler contoh } \\
\text { berdasarkan jenis kelas }
\end{array}
\end{array}
$$

Gambar 5 menunjukkan bahwa sebesar 37.5 persen contoh laki-laki, mengikuti aktivitas ekstrakurikuler yaitu selama 0.1 sampai 3.5 jam per hari, dan sebesar 24.1 persen contoh perempuan mengikuti aktivitas ekstrakurikuler selama 3.6-7 jam per minggu. Sebesar 11.1 persen contoh perempuan mengikuti aktivitas ekstrakurikuler lebih dari 7.1 jam per minggu, hal ini menunjukkan bahwa contoh perempuan lebih lama mengikuti aktivitas ekstrakurikuler dibandingkan contoh laki-laki.

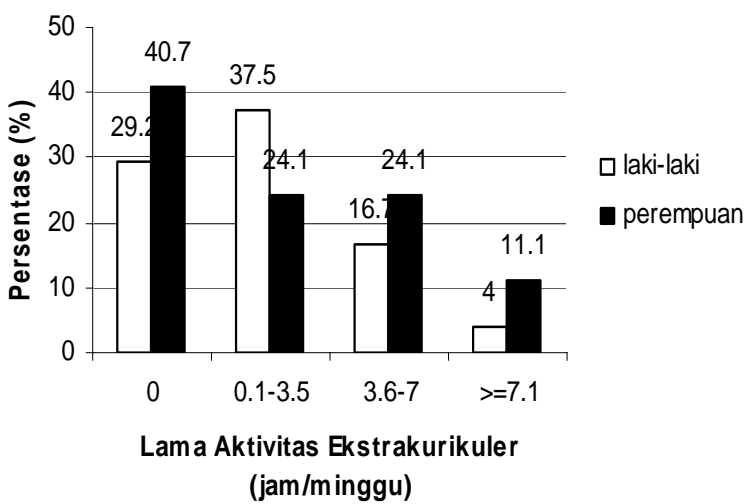

Gambar 5. Sebaran lama aktivitas ekstrakurikuler contoh berdasarkan jenis kelamin 
Prestasi Belajar

Lebih dari separuh contoh memiliki prestasi belajar kognitif pada kategori baik, dan hanya kurang dari 2 persen contoh yang memiliki nilai lebih dari cukup. Bila dilihat pada prestasi belajar psikomotorik, sebagian besar contoh termasuk kategori baik (64.1\%) dan sebesar $35.9 \%$ contoh termasuk kategori baik sekali. Sementara itu, jika dilihat dari prestasi belajar sikap, contoh menyebar pada kategori baik dan baik sekali dengan proporsi yang hampir sama, yaitu lebih dari separuh contoh memiliki prestasi baik $(51.3 \%)$ dan sebesar 48.7 persen memiliki prestasi baik sekali. Hal ini dapat disimpulkan bahwa prestasi belajar contoh secara umum berada pada kategori baik. Menurut Altaria (2004), keberhasilan prestasi belajar dipengaruhi oleh faktor internal (kecerdasan kognitif dan kepribadian) dan faktor eksternal (kondisi tempat belajar, fasilitas belajar, dan dukungan sosial).

Tabel 5. Sebaran contoh berdasarkan prestasi belajar

\begin{tabular}{|l|c|c|}
\hline \multicolumn{1}{|c|}{ Prestasi Belajar Kognitif } & \multicolumn{2}{c|}{ Jumlah } \\
\cline { 2 - 3 } & $\mathbf{n}$ & \multicolumn{2}{c|}{$\%$} \\
\hline Lebih dari cukup (61-70) & 1 & 7.3 \\
\hline Baik (71-80) & 61 & 78.2 \\
\hline Baik sekali (81-90) & 16 & 20.5 \\
\hline Total & 78 & 100 \\
\hline Prestasi Belajar Psikomotor & \multicolumn{2}{c|}{ Jumlah } \\
\hline Baik (71-80) & 50 & \multicolumn{2}{c|}{64.1} \\
\hline Baik sekali (81-90) & 28 & 35.9 \\
\hline Total & 78 & 100.0 \\
\hline \multirow{2}{*}{ Prestasi Belajar Sikap } & & Jumlah \\
\hline Baik sekali & $\mathrm{n}$ & $\%$ \\
\hline Baik & 38 & 48.7 \\
\hline Total & 40 & 51.3 \\
\hline
\end{tabular}

Lebih dari separuh contoh kelas IPA termasuk kategori baik pada penilaian prestasi belajar kognitif dan psikomotor (72.1\% dan 51.2\%), sedangkan contoh dari kelas IPS termasuk kategori baik pada semua penilaian prestasi belajar, yaitu kognitif, psikomotor, dan sikap (85.7\%, $80 \%$, dan $71.4 \%$ ). Lebih dari separuh contoh (69.8\%) dari kelas IPA berada pada kategori baik sekali pada penilaian prestasi belajar sikap. Hasil uji beda menunjukkan bahwa terdapat perbedaan nyata dalam prestasi belajar antar kelas (IPA / IPS). Hal ini diduga karena contoh yang masuk kelas IPA maupun IPS memiliki persyaratan nilai yang sama tinggi terhadap mata pelajaran tertentu yang mendukung setiap bidangnya (baik terhadap mata pelajaran IPA maupun IPS) (Tabel 6). 
Tabel 6. Sebaran prestasi belajar berdasarkan jenis kelas

\begin{tabular}{|c|c|c|c|c|}
\hline \multirow{2}{*}{ Prestasi Belajar } & \multicolumn{2}{|c|}{ IPA } & \multicolumn{2}{|c|}{ IPS } \\
\hline & $n$ & $\%$ & $n$ & $\%$ \\
\hline \multicolumn{5}{|l|}{ Kognitif } \\
\hline Lebih dari cukup (61-70) & 0 & 0 & 1 & 2.9 \\
\hline Baik (71-80) & 31 & 72.1 & 30 & 85.7 \\
\hline Baik Sekali (81-90) & 12 & 27.9 & 4 & 11.4 \\
\hline Total & 43 & 100 & 35 & 100 \\
\hline p-value & \multicolumn{4}{|c|}{0.000} \\
\hline \multicolumn{5}{|l|}{ Psikomotor } \\
\hline Baik (71-80) & 22 & 51.2 & 28 & 80 \\
\hline Baik Sekali (81-90) & 21 & 48.8 & 7 & 20 \\
\hline Total & 43 & 100 & 35 & 100 \\
\hline p-value & \multicolumn{4}{|c|}{0.000} \\
\hline \multicolumn{5}{|l|}{ Sikap } \\
\hline Baik & 13 & 30.2 & 25 & 71.43 \\
\hline Baik Sekali & 30 & 69.8 & 10 & 28.6 \\
\hline Total & 43 & 100 & 35 & 100 \\
\hline p-value & \multicolumn{4}{|c|}{0.001} \\
\hline
\end{tabular}

Tabel 7 menunjukkan bahwa lebih dari separuh contoh laki-laki termasuk kategori baik pada penilaian prestasi belajar (kognitif, psikomotorik, dan sikap), begitu pula prestasi belajar perempuan dimana lebih dari separuh contoh termasuk kategori baik pada prestasi belajar kognitif, psikomotor, dan sikap (75.9\%, 59.3\%, dan 100\%). Hasil uji beda menunjukkan bahwa terdapat perbedaan nyata dalam prestasi belajar (kognitif dan sikap) antara jenis kelamin.

Tabel 7. Sebaran prestasi belajar berdasarkan jenis kelamin

\begin{tabular}{|c|c|c|c|c|}
\hline \multirow{2}{*}{ Prestasi Belajar Kognitif } & \multicolumn{2}{|c|}{ Laki-laki } & \multicolumn{2}{|c|}{ Perempuan } \\
\hline & $\mathbf{n}$ & $\%$ & $\mathbf{n}$ & $\%$ \\
\hline Lebih dari cukup (61-70) & 1 & 4.2 & 0 & 0 \\
\hline Baik (71-80) & 20 & 83.3 & 41 & 75.9 \\
\hline Baik sekali (81-90) & 3 & 12.5 & 13 & 24.1 \\
\hline Total & 78 & 100 & 78 & 100 \\
\hline$p$-value & \multicolumn{4}{|c|}{0.032} \\
\hline \multirow{2}{*}{ Prestasi Belajar Psikomotor } & \multicolumn{2}{|c|}{ Laki-laki } & \multicolumn{2}{|c|}{ Perempuan } \\
\hline & $\mathrm{n}$ & $\%$ & $\mathrm{n}$ & $\%$ \\
\hline Baik (71-80) & 18 & 75 & 35 & 59.3 \\
\hline Baik sekali (81-90) & 6 & 25 & 22 & 40.7 \\
\hline Total & 78 & 100 & 78 & 100.0 \\
\hline$p$-value & \multicolumn{4}{|c|}{0.226} \\
\hline \multirow{2}{*}{ Prestasi Belajar Sikap } & \multicolumn{2}{|c|}{ Laki-laki } & \multicolumn{2}{|c|}{ Perempuan } \\
\hline & $\mathrm{n}$ & $\%$ & $\mathrm{n}$ & $\%$ \\
\hline Baik & 24 & 100 & 54 & 100 \\
\hline Total & 78 & 100 & 78 & 100.0 \\
\hline$p$-value & \multicolumn{4}{|c|}{0.006} \\
\hline
\end{tabular}

Hubungan Karaktersitik Individu dengan Gaya Pengasuhan Orangtua

Hubungan Jenis Kelamin dengan Gaya Pengasuhan Orangtua. Hasil korelasi Spearman menunjukkan bahwa jenis kelamin dinyatakan tidak memiliki hubungan nyata dengan gaya pengasuhan orangtua $(p>0.05)$. Maksudnya, apapun jenis kelamin anak maka tidak ada keterkaitannya dengan gaya pengasuhan yang 
diterapkan orangtua. Hal ini diduga karena orangtua dapat menerapkan gaya pengasuhan yang sama kepada anak yang berjenis kelamin laki-laki maupun perempuan, atau sebaliknya menerapkan gaya pengasuhan berbeda kepada anak yang berjenis kelamin laki-laki maupun perempuan.

Hubungan Urutan Anak dengan Gaya Pengasuhan Orangtua. Tabel 8 menunjukkan bahwa urutan anak tidak memiliki hubungan dengan gaya pengasuhan orangtua. Maksudnya, apapun urutan kelahiran anak maka tidak ada keterkaitannya dengan gaya pengasuhan yang orangtua terapkan. Hal ini diduga karena para orangtua memiliki pola pengasuhan yang konsisten dan tidak diskriminasi dalam mengasuh anak, sehingga apapun urutan kelahirannya maka orangtua menerapkan gaya pengasuhan yang sama pada setiap urutan anak.

Tabel 8. Hasil uji korelasi Spearman karakteristik individu dengan gaya pengasuhan orangtua

\begin{tabular}{|l|c|c|c|}
\hline \multicolumn{1}{|c|}{ Variabel } & Jenis kelamin & Urutan anak & Gaya pengasuhan orangtua \\
\hline Jenis kelamin & 1.000 & & \\
\hline Urutan anak & -0.017 & 1.000 & \\
\hline Gaya pengasuhan orangtua & 0.094 & 0.168 & 1.000 \\
\hline
\end{tabular}

* signifikan pada taraf $p<0.05$; ** signifikan pada taraf $p<0.01$

Hubungan Karakteristik Keluarga dengan Gaya Pengasuhan Orangtua

Hubungan Besar Keluarga dengan Gaya Pengasuhan Orangtua. Hasil uji korelasi Spearman menunjukkan besar keluarga tidak memiliki hubungan dengan gaya pengasuhan orangtua. Hal ini menunjukkan berapa pun besar jumlah anggota keluarga contoh, tidak ada kaitannya dengan gaya pengasuhan yang orangtua terapkan. Menurut Widiana (2002), adanya kepadatan dalam keluarga akan mengganggu pola corak hubungan antar anggota keluarga sehingga jalinan komunikasi diantara anggota keluarga tidak berjalan sebagaimana mestinya.

Hubungan Pendidikan Orangtua dengan Gaya Pengasuhan Orangtua. Pendidikan orangtua tidak berhubungan dengan gaya pengasuhan orangtua. $\mathrm{Hal}$ ini menunjukkan apapun tingkat pendidikan orangtua (ayah maupun ibu) tidak memiliki keterkaitan dengan gaya pengasuhan orangtua. Pendidikan orangtua tidak berhubungan dengan gaya
Hubungan Pendapatan dengan Gaya Pengasuhan Orangtua. Hasil uji korelasi Spearman menunjukkan tingkat pendapatan tidak berhubungan dengan gaya pengasuhan orangtua. Tidak adanya hubungan pendapatan dengan gaya pengasuhan orangtua diduga karena ada faktor lain, seperti pengalaman orangtua contoh dalam menerima gaya pengasuhan yang diberikan orangtuanya dahulu.

\section{Hubungan Gaya Pengasuhan}

\section{Orangtua dengan Kecerdasan} Emosional

Gaya pengasuhan orangtua berhubungan nyata positif $(p<0.01)$ dengan kecerdasan emosional. Ini berarti semakin baik gaya pengasuhan orangtua, maka semakin baik kecerdasan emosional anak. Hal ini didukung dengan pernyataan Megawangi (2004) bahwa orangtua yang menerapkan gaya pengasuhan dengan membuat anak merasa disayangi, dilindungi, dan diberi dukungan oleh orangtua, dapat membentuk kepribadian anak yang memiliki kepribadian pro-sosial dan peduli terhadap lingkungannya. 
Hubungan Gaya Pengasuhan Orangtua dengan Kesadaran Emosi Diri. Gaya pengasuhan orangtua berhubungan nyata positif dengan kesadaran emosi diri. Hal ini menunjukkan bahwa semakin baik gaya pengasuhan yang diberikan orangtua, maka semakin baik kesadaran emosi diri anak.

Gaya pengasuhan orangtua mengabaikan, tidak menyetujui, dan laissez faire menunjukkan tidak berhubungan dengan kesadaran emosi diri. Hal ini menunjukkan bahwa kemungkinan ada kondisi dimana kesadaran emosi diri bagus meskipun gaya pengasuhan negatif orangtua tinggi. Dalam kondisi tersebut, diduga faktor lingkungan di luar rumah, seperti guru dan teman mendukung pengembangan kecerdasan emosi positif. Gaya pengasuhan orangtua pelatih emosi tidak berhubungan nyata dengan kesadaran emosi. Hal ini diduga karena lingkungan di luar rumah memberikan pengaruh negatif atau tidak kondusif terhadap pengembangan kesadaran emosi diri.

Hubungan Gaya Pengasuhan Orangtua dengan Pengelolaan Emosi. Gaya pengasuhan orangtua tidak berhubungan nyata dengan pengelolaan emosi diri. Hal ini diduga karena orangtua dalam menerapkan pola pengasuhan kombinasi dari orangtua menerima dan menolak, sehingga mempengaruhi pengelolaan emosi anak. Menurut Goleman (1997), perlakuan yang orangtua terapkan dalam mendidik anak dapat menjadikan kesan mendalam dalam diri seorang anak.

Hasil korelasi Spearman menunjukkan gaya pengasuhan orangtua mengabaikan, orangtua tidak menyetujui berhubungan nyata negatif dengan variabel pengelolaan emosi $(p<0.01)$. Hal ini berarti semakin orangtua cenderung menerapkan gaya pengasuhan mengabaikan dan orangtua tidak menyetujui, maka semakin rendah pengelolaan emosi contoh. $\begin{array}{crr}\text { Hasil } & \text { korelasi } & \text { Spearman } \\ \text { menunjukkan } & \text { bahwa } & \text { gaya }\end{array}$ pengasuhan orangtua pelatih emosi berhubungan nyata positif dengan pengelolaan emosi $(p<0.05)$. Hubungan tersebut memiliki arti bahwa orangtua menerima setiap perkembangan emosi dan perilaku anak, sehingga pengelolaan emosi anak menjadi semakin baik. Gaya pengasuhan orangtua laissez faire tidak berhubungan nyata dengan pengelolaan emosi. Hal ini menunjukkan bahwa gaya pengasuhan laissez faire yang diterapkan orangtua, tidak ada keterkaitannya dengan pengelolaan emosi anak.

Hubungan Gaya Pengasuhan Orangtua dengan Motivasi Diri. Hasil uji korelasi Spearman menunjukkan bahwa orangtua mengabaikan berhubungan nyata negatif dengan motivasi diri $(p<0.01)$. Artinya, semakin orangtua mengabaikan maka semakin rendah motivasi diri anak. Secara umum, gaya pengasuhan orangtua berhubungan nyata positif dengan motivasi diri $(p<0.01)$. Hal ini menjelaskan semakin baik orangtua dalam menerapkan gaya pengasuhan, maka semakin baik motivasi diri yang dimiliki anak..

Hubungan Gaya Pengasuhan Orangtua dengan Seni Membina Hubungan. Hasil uji korelasi Spearman menunjukkan bahwa gaya pengasuhan orangtua mengabaikan berhubungan nyata negatif dengan seni membina hubungan. Hal ini menunjukkan bahwa semakin orangtua mengabaikan contoh, maka semakin rendah kemampuan contoh dalam membina hubungan.

Gaya pengasuhan orangtua pelatih emosi menunjukkan hubungan nyata positif dengan seni membina hubungan $(p<0.01)$. Artinya, semakin baik orangtua sebagai pelatih emosi, maka semakin baik kemampuan anak dalam membina hubungan. Orangtua pelatih emosi menghargai dan menghormati setiap pemikiran 
anaknya, dan mengikutsertakan anak dalam pengambilan keputusan.

Bila dilihat secara umum, gaya pengasuhan orangtua berhubungan nyata positif dengan seni membina hubungan. Hal ini menunjukkan semakin baik gaya pengasuhan yang orangtua terapkan, maka semakin baik juga anak dalam seni membina hubungan. Hal ini didukung dengan pernyataan Desmita (2005) bahwa kelekatan hubungan antara orangtua dan anak merupakan dasar bagi perkembangan emosi dan sosial anak.

Hubungan Kecerdasan Emosional dengan Aktivitas dan Prestasi Belajar

Kecerdasan emosional memegang peranan penting dalam berbagai aktivitas dan prestasi belajar. Skala kecerdasan emosional merupakan salah satu faktor pendukung pada diri anak untuk mampu melaksanakan berbagai aktivitas dan prestasi belajar dengan baik.

Hubungan Kecerdasan

Emosional dengan Aktivitas. Hasil korelasi Spearman pada skala kecerdasan emosional seni membina hubungan berhubungan nyata positif dengan aktivitas ekstrakurikuler $(p<0.01)$. Hal ini menjelaskan bahwa siswa yang mengikuti aktivitas ektrakurikuler, memiliki kemampuan seni membina hubungan yang baik. Skala kecerdasan emosional pada motivasi diri berhubungan nyata positif dengan lama aktivitas belajar di rumah. Artinya, semakin tinggi motivasi yang dimiliki, maka semakin lama contoh belajar di rumah.

Hasil korelasi Spearman menunjukkan bahwa kecerdasan emosional berhubungan nyata positif dengan lama aktivitas rumah tangga. Artinya, semakin baik kecerdasan emosional contoh, maka semakin lama aktivitas rumah tangganya. Hal ini diduga karena contoh memiliki kualitas emosional yang baik dalam melaksanakan suatu pekerjaan, kualitas emosional yang dimiliki yaitu ketekunan.

Skala kecerdasan motivasi diri berhubungan nyata negatif dengan lama aktivitas waktu luang. Artinya, semakin baik motivasi diri contoh, maka semakin rendah aktivitas waktu luangnya. Hal ini diduga karena adanya dorongan dari dalam diri contoh untuk melakukan aktivitas yang lebih berguna, seperti belajar, membuat contoh mengurangi aktivitas waktu luangnya.

Hasil uji statistik menunjukkan bahwa kecerdasan emosional tidak berhubungan nyata dengan aktivitas bersosialisasi. Artinya, baik tidaknya kecerdasan emosional contoh tidak ada keterkaitannya dengan aktivitas bersosialisasi. Hal ini diduga ada faktor lain yang membuat contoh bersosialisasi atau tidak bersosialisasi, yaitu peer group (teman sebaya).

Hubungan Kecerdasan Emosional dengan Prestasi Belajar. Hasil korelasi Spearman menunjukkan kecerdasan emosional berhubungan nyata dengan prestasi belajar kognitif dan psikomotor. Hal ini berarti bahwa semakin tinggi kecerdasan emosional, maka semakin baik prestasi belajar kognitif dan psikomotor contoh.

Hasil uji Spearman menunjukkan bahwa seni membina hubungan berhubungan nyata positif dengan prestasi belajar kognitif dan psikomotor $(p<0.01)$. Artinya, semakin baik kemampuan membina hubungan, maka semakin baik prestasi belajarnya (kognitif dan psikomotor). Hal ini diduga karena contoh memiliki kemampuan bekerjasama yang baik dalam membentuk kelompok belajar, baik kelompok belajar yang ada di sekolah maupun di luar sekolah.

Hasil uji Spearman

menunjukkan bahwa empati berhubungan nyata positif $(p<0.05)$ dengan prestasi belajar psikomotor. Artinya, semakin tinggi empati anak, maka semakin baik prestasi belajarnya psikomotornya. Hal ini diduga karena kemampuan memahami setiap tugas 
yang diajarkan dan di contohkan oleh guru dengan baik di kelas dan di luar kelas.

Motivasi diri berhubungan nyata positif dengan prestasi belajar pada dimensi sikap $(p<0.05)$. Hal ini menunjukkan bahwa semakin tinggi motivasi diri contoh dalam belajar, maka semakin baik prestasi sikap contoh. Hal ini diduga karena keinginan, kehendak atau kebutuhan dalam diri anak untuk mengikuti setiap mata pelajaran membuat contoh selalu berusaha dan bekerja keras dalam belajar.

Hubungan Aktivitas dengan Prestasi Belajar

Hasil korelasi Spearman menunjukkan bahwa aktivitas belajar di rumah tidak berhubungan dengan prestasi belajar (kognitif, psikomotor, dan sikap). Artinya, rajin atau tidaknya contoh belajar di rumah, maka tidak ada keterkaitan dengan prestasi belajar (kognitif, psikomotor, dan sikap). Hal ini diduga ada faktor lain yang mempengaruhi prestasi belajar, seperti keturunan.

Hasil korelasi Spearman menunjukkan bahwa aktivitas ekstrakurikuler berhubungan nyata positif dengan prestasi belajar psikomotor $(p<0.01)$. Hal ini berarti semakin aktif contoh mengikuti aktivitas ekstrakurikuler, maka semakin baik prestasi belajar psikomotor..

Aktivitas rumah tangga berhubungan nyata positif dengan prestasi belajar sikap. Maksudnya, semakin lama aktivitas di rumah tangga, maka semakin baik prestasi belajar sikap. Bila dilihat dari hasil korelasi Spearman yang menunjukkan bahwa aktivitas rumah tangga berhubungan nyata dengan kecerdasan emosional, sedangkan kecerdasan emosional juga berhubungan nyata dengan prestasi belajar contoh, maka dapat dipahami jika aktivitas rumah tangga berhubungan dengan prestasi belajar contoh.

Hasil korelasi Spearman menunjukkan bahwa lama aktivitas waktu luang tidak berhubungan dengan prestasi belajar. Artinya, banyak atau sedikitnya aktivitas waktu luang contoh, maka tidak ada keterkaitannya dengan prestasi belajar.

Lama aktivitas bersosialisasi contoh tidak berhubungan nyata dengan prestasi belajar (kognitif, psikomotor, dan sikap). Artinya, aktif atau tidaknya contoh bersosialisasi tidak ada keterkaitannya dengan prestasi belajar contoh. Hal ini diduga karena kemungkinan adanya macammacam hubungan dalam bersosialisasi, faktor genetik, faktor efisiensi dalam belajar, dan strategi dalam belajar.

\section{SIMPULAN DAN SARAN}

Simpulan

$$
\text { Kecerdasaan emosional }
$$

dipengaruhi oleh gaya pengasuhan orangtua. Sementara itu, kecerdasan emosional laki-laki dan perempuan tidak menunjukkan adanya perbedaan. Orang tua yang menerapkan gaya pengasuhan pelatih emosi mempengaruhi pengelolaan emosi anak remaja dalam seni membina hubungan. Berdasarkan prestasi belajar anak, ditemukan adanya hubungan nyata antara prestasi belajar dengan perbedaan antar jenis kelas dan jenis kelamin. Prestasi belajar pada anak remaja dipengaruhi oleh aktivitas ekstrakurikuler maupun aktivitas rumah tangga.

\section{Saran \\ Mengingat adanya hubungan antara gaya pengasuhan dengan kecerdasan emosional, maka hendaknya orangtua memperhatikan perkembangan emosi anak dengan menerapkan gaya pengasuhan yang dapat mendukung perkembangan emosi anak. Mengingat adanya}




\begin{abstract}
hubungan antara kecerdasan emosional dengan aktivitas ekstrakurikuler dan prestasi belajar, maka hendaknya orangtua berusaha untuk mendorong perkembangan emosional anaknya sehingga anak dapat berprestasi baik dibidang akademik maupun nonakademik. Mengingat pentingnya kecerdasan emosional bagi pendidikan dan kualitas sumberdaya manusia, maka pihak sekolah dan Departemen Pendidikan Nasional diharapkan dapat lebih memperhatikan upaya pengembangan kecerdasan emosional dalam sistem pendidikan di sekolah.
\end{abstract}

\section{DAFTAR PUSTAKA}

[BPS] Badan Pusat Statistik. 2002. Produk Domestik Regional Bruto Kota Sukabumi. Sukabumi: BPS.

Desmita. 2005. Psikologi Perkembangan. Bandung: Rosda.

Goleman, D. 1997. Kecerdasan Emosional: Mengapa El Lebih Penting dari IQ. Jakarta: PT Gramedia Pustaka Utama.

Guhardja S, Puspitawati H, Hartoyo, Hastuti D. 1992. Manajemen Sumberdaya Keluarga. Diktat Jurusan Gizi Masyarakat dan Sumberdaya Keluarga, Fakultas Pertanian. Bogor: Institut Pertanian Bogor.

Gunarsa, S.D., Gunarsa, S.Y. 2004. Psikologi Praktis: Anak, Remaja dan Keluarga. Jakarta: PT. BPK. Gunung Mulia.

Megawangi, R. 2004. Pendidikan Karakter (Solusi yang Tepat untuk Membangun Bangsa). Jakarta: Indonesia Herritage Foundation.

Pertiwi, A. F., Baswardono, R. A. Tagor, K. Sawitro. 1997. Mengembangkan Kecerdasan Emosi Anak. Jakarta: Aspirasi Pemuda.

Santrock, J.W. 1997. Life-Span Development. Times Mirror Higher Education Group. Inc, America.

Soetjiningsih. 1995. Tumbuh Kembang Anak. Di dalam: IG. N Gde Ranuh, editor. Jakarta: EGC.

Sukiat. 1986. Motivasi dan Intelegensi. Dalam Sadli S. (ed.), Inteligensi, bakat dan Test IQ (hlm. 125-133). Jakarta : Gaya Favorit Press.

Umar, H. 2003. Metode Riset Perilaku Konsumen Jasa. Jakarta: Ghalid Indonesia.

1 Departemen Gizi Masyarakat dan

Sumberdaya Keluarga, IPB

2 Departemen IImu Keluarga dan Konsumen, IPB

Alamat Korespondensi:

Melly Latifah

Departemen IImu Keluarga dan Konsumen, Fakultas Ekologi Manusia IPB

Jl. Lingkar Kampus IPB Darmaga 16680

Telp. (0251) 8628303, Fax. (0251) 8627432 